\title{
Measuring Environmental Inequality
}

\author{
James K. Boyce, ${ }^{*}$ Klara Zwickl ${ }^{* *}$ and Michael Ash $^{* * *}$
}

Revised version: 5 December 2015

\begin{abstract}
This study presents alternative measures of environmental inequality in the 50 U.S. states for exposure to industrial air pollution. We examine three methodological issues. First, to what extent are environmental inequality measures sensitive to spatial scale and population weighting? Second, how do sensitivities to different segments of the overall distribution affect rankings by these measures? Third, how do vertical and horizontal (inter-group) inequality measures relate to each other? We find substantive differences in rankings by different measures and conclude that no single indicator is sufficient for addressing the entire range of equity concerns that are relevant to environmental policy; instead multiple measures are needed.
\end{abstract}

Keywords: Inequality measurement, Gini coefficient, environmental justice, air pollution.

JEL codes: I14, Q53, Q56, R11.

Acknowledgements: Research for this paper was supported by the Institute for New Economic Thinking (INET) Grant No. INO13-00028 and by the National Science Foundation Grant No. SES-1060904. We are also grateful to the Research Database Complex (RDC) at Indiana University, funded by Shared University Research grants from IBM, Inc., for hosting the database for this project. We thank two anonymous referees for helpful comments and suggestions.

\footnotetext{
* Political Economy Research Institute and Department of Economics, University of Massachusetts Amherst. Email: boyce@econs.umass.edu.

** Institute for Ecological Economics, Department of Socioeconomics, Vienna University of Economics and Business. Email: klara.zwickl@wu.ac.at.

*** Department of Economics and Center for Public Policy and Administration, University of Massachusetts Amherst. Email: mash@econs.umass.edu.
} 


\section{Introduction}

Pollution is a public bad - the opposite of a public good - but its burdens are not shared equally across the public. In the United States, a large body of research has documented the disproportionate environmental burdens faced by racial and ethnic minorities and low-income households (see, for example, Szasz and Meuser 1997; Ash and Fetter 2004; Mohai 2008; Bullard et al. 2011). These and other disparities are important features of many environmental landscapes.

In examining environmental inequalities, a number of studies have applied inequality measures that were originally developed to measure the distribution of income and wealth. Many of these have focused on international inequalities, including inter-country disparities in carbon emissions (Heil and Wodon 2000; Duro 2012) and resource use (Druckman and Jackson 2008). With the exception of one study in the state of Maine (Bouvier 2014), however, inequality measures have not been applied to the distribution of industrial air pollution exposure within the U.S.

In this study we present several different inequality measures for industrial air pollution exposure in the U.S. states and compare the resulting inter-state rankings. The extent of pollution exposure disparities between racial and ethnic groups and income classes has been found to vary considerably across U.S. regions (Zwickl et al. 2014) and metropolitan areas (Downey 2007). Here we conduct our analysis at the state level, intermediate between larger regions and smaller metropolitan areas. Inter-state comparisons are of interest because states vary both in the strength and of environmental regulations and in the extent to which their environmental policies incorporate explicit distributional objectives (Bonorris 2010).

Using data on exposure to industrial air toxics from the Risk-Screening Environmental Indicators (RSEI) database of the U.S. Environmental Protection Agency (EPA), we compute several measures of inequality to consider three important questions:

- First, to what extent are measures of environmental inequality sensitive towards the spatial scale and population weights? Previous studies have emphasized the importance of fine spatial disaggregation to avoid the so-called "ecological fallacy” - erroneous inferences about smaller geographical units or individuals drawn from data on larger aggregates (Ash and Fetter 2004). We apply a wellknown measure of inequality - the Gini coefficient - to air pollution exposure and compare measures based on 810 meter-square grid cells to those based on (generally larger) census tracts to examine whether these alternative units of 
observation yield substantially different results. In addition, we examine the effect of weighting these spatial units by their population.

- Second, how do the sensitivities of inequality measures to different ranges of the distribution affect inter-state rankings? In the case of industrial air pollution, exposures often are concentrated at the top of the distribution: many households are exposed to relatively low levels, while a small percentage are exposed to very high levels. Researchers and policy makers may be particularly interested in measures that are more sensitive to differences within the upper range of the distribution.

- Third, how do inter-state rankings based on vertical inequality compare to rankings based on horizontal inequality? Vertical measures of inequality differentiate the population solely by the variable of interest (here, pollution exposure), whereas horizontal measures partition the population on the basis of other characteristics. Here we consider pollution exposure differences by minority status and income, criteria in the environmental justice policies of federal and state agencies.

Section 2 reviews motivations for measuring environmental inequality - why the distribution of environmental harm may matter as well as its overall magnitude. Section 3 discusses the data used in our analysis. Section 4 explains the methods used to calculate alternative measures of exposure inequality, and section 5 presents the results of applying these to industrial air pollution exposure in the 50 states. Section 6 concludes with a discussion of the policy implications of our findings and potential avenues for further research on environmental inequality.

\section{Welfare effects of environmental inequality}

As scholars of income and wealth distribution have pointed out, the choice of inequality measures is not only a technical question but also depends on underlying notions of social welfare (Atkinson 1970). Before discussing alternative measures, therefore, it is useful to consider the welfare implications of environmental inequality.

The distribution of environmental quality matters for social welfare for at least three reasons. The first is intrinsic, founded on the normative principle that every person has an equal right to a clean and safe environment. The second is instrumental: environmental quality can have important impacts on opportunities to lead a healthy and productive life, and equality of opportunities is widely accepted as a normative goal. The third, also instrumental, is that environmental quality can have important impacts on economic 
outcomes for individuals and communities, the distribution of which has been the primary concern of economists who study inequality. This section discusses these rationales with a focus on air pollution, which is characterized by the World Health Organization (2014) as "the world's largest single environmental health risk."

\subsection{Intrinsic value of environmental equity}

The normative principle that every person has the right to a clean and safe environment has been widely affirmed in recent decades in the most fundamental of legal documents, national constitutions. The post-apartheid Constitution of the Republic of South Africa, for example, states: "Every person shall have the right to an environment which is not detrimental to his or her health or well-being." The Constitution of Argentina similarly affirms, "All residents enjoy the right to a healthy, balanced environment." The Constitution of Chile guarantees to all persons "the right to live in an environment free from contamination." The Constitution of Portugal provides, "Everyone shall have the right to a healthy and ecologically balanced human environment and the duty to defend it." $^{1}$

The U.S. Constitution does not explicitly guarantee the right to a clean and safe environment, but implicit endorsement of this principle is "already contained in the thousands of pages of federal environmental statutes and regulations now on the books" (Meltz 1999). The Clean Air Act, for example, directs the EPA to promulgate and enforce ambient air quality standards, "the attainment and maintenance of which ... are requisite to protect the public health."2 Explicit affirmations of the right to a clean and safe environment were added to a number of U.S. state constitutions starting in the 1970s. The Massachusetts Constitution states, "The people shall have the right to clean air and water." The Hawaii Constitution provides, "Each person has the right to a clean and healthful environment, as defined by laws relating to environmental quality, including control of pollution and conservation, protection and enhancement of natural resources." The Illinois Constitution affirms, "Each person has the right to a healthful environment." The Pennsylvania Constitution specifies, "The people have a right to clean air, pure water, and to the preservation of the natural, scenic, historic and esthetic values of the environment." The Montana Constitution states, in language that evokes the U.S. Declaration of Independence, "All persons are born free and have certain inalienable rights. They include the right to a healthful environment..."

\footnotetext{
${ }^{1}$ Similar statements appear in the Constitutions of many other nations. For examples and discussion, see Popovic (1996).

242 U.S. Code $\$ 7409$ - National primary and secondary ambient air quality standards.
} 
By asserting the normative principle that all persons have a right to a clean environment, these provisions place an intrinsic value on the distribution of environmental quality. Regardless of how the practical matter of translating this goal into policies is handled including the question of how clean the environment must be in order to qualify as "clean" - this principle implies that the environmental rights of some should not take precedence over the environmental rights of others.

Presidential Executive Order 12898, issued by Bill Clinton in 1994, directs each U.S. government agency to take steps to identify and rectify "disproportionately high and adverse human health or environmental effects of its programs, policies, and activities on minority populations and low-income populations," explicitly inscribing equity across groups defined on the basis of race, ethnicity and economic status into federal environmental policy. Many states have also adopted environmental justice policies (Bonorris 2010). In a proclamation marking the $20^{\text {th }}$ anniversary of the executive order on environmental justice, President Barack Obama reaffirmed "every American's right to breathe freely, drink clean water, and live on uncontaminated land” (Obama 2014).

\subsection{Equality of opportunity}

A second motivation for concern about environmental inequality is its impact on equality of opportunity, which is widely accepted as a normative goal. "Much more important than inequality of outcomes among adults is inequality of opportunity among children," write the authors of the World Bank's Human Opportunity Index, noting that "the idea of giving people equal opportunity early in life, whatever their socioeconomic background, is embraced across the political spectrum" (Barros et al. 2009, p. xvii).

Children are especially vulnerable to the health impacts of pollution, and environmental quality can significantly affect a child's life chances (Currie 2011). The impacts extend to the odds of survival. For example, a study of the impact of reduced air pollution in the U.S. during the 1981-82 recession found that for each one percent decrease in total suspended particulates, infant mortality declined by 0.35 percent (Chay and Greenstone 2003). Emissions controls implemented by the state of California are estimated to have prevented approximately 1,000 infant deaths from carbon monoxide exposure in the 1990s (Currie and Neidell 2005).

Air pollution also has adverse impacts on fetal health (Currie et al. 2009). Researchers have concluded that "a substantial proportion of cases of low birthweight at term could be prevented in Europe if urban air pollution was reduced" (Pedersen et al. 2013). Fetal exposure to industrial chemicals has been linked to neurodevelopmental disabilities 
including autism, attention-deficit hyperactivity disorder, dyslexia and other cognitive impairments (Grandjean and Landrigan 2014).

Exposure to airborne toxics has been found to have statistically significant negative effects on school test scores in metropolitan Los Angeles (Pastor et al. 2002, 2004). A study in Louisiana, found that proximity to Toxics Release Inventory (TRI) facilities and highvolume emitters of developmental neurotoxins is significantly related to school performance (Lucier et al. 2011). Even transitory exposure to high levels of airborne particulates on exam days has been shown to have significant adverse impacts on student performance on high-stakes tests, leading in turn to negative effects on post-secondary education and adult earnings (Lavy et al. 2014).

A further pathway by which air pollution affects educational opportunities is by causing school absences due to asthma and other illnesses. A study of elementary and middle school children in Texas found that air pollution had significant adverse effects on school attendance (Currie et al. 2009). A Michigan study found that schools located in neighborhoods with the highest industrial air pollution levels had the lowest attendance rates as well as the highest proportions of students who failed to meet state educational testing standards, after controlling for effects of other variables (Mohai et al. 2011).

\subsection{Equality of economic outcomes}

The distribution of pollution also has impacts on the distribution of economic outcomes, via impacts on property values, days lost from work and health costs. Air pollution has long been known to reduce property values (Anderson and Crocker 1971). Housing values within a one-mile radius have been found to decrease by $1.5 \%$ when a TRI facility opens and to rise by $1.5 \%$ when one closes (Currie et al. 2015). Air quality improvements following implementation of the Clean Air Act led to an estimated $\$ 45$ billion increase in housing values in the 1970s (Chay and Greenstone 2005).

Air pollution also results in lost workdays. An analysis by EPA scientists estimated that airborne particulate matter from industrial point sources is responsible for 1.6 million lost workdays annually in the U.S. (Fann et al. 2013). Exposure to air pollution has also been shown to have statistically significant adverse impacts on worker productivity (Graff Zivin and Neidell 2012).

The health costs of air pollution are large and unequally distributed. Announcing its Mercury and Air Toxics Standards for power plants in December 2014, the EPA estimated that they will yield annual health benefits valued at between \$37 billion and 
$\$ 90$ billion, and that these are "especially important to minority and low income populations who are disproportionately impacted by asthma and other debilitating health conditions" (U.S. EPA 2014).

The well documented inverse relationship between health and socioeconomic status may arise in part from differences in pollution exposure (Evans and Kantrowitz 2002). A study of New York City's Bronx borough found that poor and minority populations are more likely to live in proximity to noxious land uses, including TRI facilities, and that this is associated with a $66 \%$ increase in the likelihood of hospitalization for asthma (Maantay 2007). Exposure to multiple hazards has cumulative impacts (Brender et al. 2011), and interactions with vulnerabilities linked to socioeconomic status can exacerbate health effects of environmental hazards (Morello-Frosch et al. 2011).

\section{Mapping exposure to industrial air toxics in the United States}

We measure industrial air toxics exposure using geographic microdata from the U.S. EPA's Risk Screening Environmental Indicators (RSEI version 2.3.1) model for the year 2010. The RSEI model is based on TRI data on air releases of more than 400 chemicals from more than 15,000 facilities. The model maps the dispersion of these releases, incorporating information on stack heights, exit gas velocities, wind patterns, and chemical decay rates in order to estimate ambient concentrations in grid cells, each 810 meters square, within a 50-km radius around each facility. To measure total exposure aggregated across chemicals RSEI uses toxicity weights based on chronic human health effects.

The RSEI data provide the best available measure of exposure to industrial air toxics. The data do not include emissions from mobile sources and small point sources, which also contribute to overall air pollution. In the communities that face the most severe air pollution burdens, however, the industrial point sources included in the RSEI database often loom large (Boyce and Pastor 2012).

Median household exposure to industrial air toxics varies widely across the states, as shown in Figure 1a. The highest median exposure (in Utah) is roughly one thousand times more than the lowest (in Vermont). To examine intra-state variations, we first calculate toxicity-weighted exposures for each of the state's RSEI grid cells, aggregated across all facilities whose releases impact that cell. We use a crosswalk to map the gridcells to census blocks, which are the finest level of spatial resolution in the U.S. Census. We then compute exposure at the level of census tracts, calculated as the area-weighted 
average of exposure in the tract's constituent blocks. ${ }^{3}$ We find that exposure is distributed quite unevenly within states, as well as across them, as shown in Figure 1b. For example, the same state may include census tracts that rank both in the highest and lowest national exposure quintiles.

[insert Figures 1a \& 1b here]

When measuring inequality in the distribution of income and wealth, the unit of observation typically is the individual or the household. In the case of spatial variables, such as pollution exposure, the choice of the unit of observation for measuring inequality is less straightforward. To guard against the "ecological fallacy" - where conclusions drawn from aggregate data do not apply at finer levels of disaggregation - it is desirable to base calculations on the smaller units of observation. It the present case, the smallest unit is the 810 meter x 810 meter RSEI grid cell. There are roughly 15 million grid cells nationwide, 9.7 million of which are exposed to industrial air pollution according to the RSEI model. Although grid cells have a fixed area, their population density can vary greatly.

Alternatively, we can compute inequality measures using the 74,002 census tracts as the unit of observation. Census tracts often correspond to what residents consider to be their "neighborhoods," and for this reason inequality measures constructed on this basis are of intrinsic interest. ${ }^{4}$ Tracts are constructed by the Census Bureau to include roughly 4,000 persons each; hence they vary in area due to differences in population density. Although grid cells generally provide finer spatial resolution, tracts are smaller than grid cells in densely populated urban areas. The number of grid cells per census tract ranges from 0.06 in densely populated neighborhoods of New York City and Boston to tens of thousands in parts of western states such as Nevada and Alaska.

The choice of whether to define spatial units on the basis of equal area or equal population is important from a policy standpoint as well for inequality measurement. Disparities across units of equal area could be reduced by prioritizing the most polluted areas, regardless of how many people live there. Such a policy approach could be justified on the normative premise that each individual should have equal access to environmental quality, regardless of the population density in the place they reside.

\footnotetext{
${ }^{3}$ We censor pollution exposure at the nationwide population-weighted 97th percentile (that is, we cap exposure at this value) to reduce the sensitivity of our results to outliers.

${ }^{4}$ Census tracts have been used as proxies for neighborhoods in analyzing environmental disparities (Zwickl and Moser 2014), housing segregation (Brueckner and Rosenthal 2009), unemployment (Topa 2001) and subprime credit markets (Richter and Craig 2013).
} 
Disparities across units of equal population could be reduced by prioritizing areas that are more densely populated, even if they are not the most polluted. Such an approach could be justified on the normative premise that environmental policy should maximize the sum total of human health benefits.

Here our focus is the distribution of pollution exposure across the population. For this reason we use population weights in calculating our inequality measures. Because grid cells generally are smaller than census tracts, a comparison between population-weighted inequality measures calculated on these two spatial bases can shed light on how much inequality arises from within-tract variations. In the case of income inequality, comparisons of measures calculated on the basis of tract-level versus household-level data show that a substantial component of overall inequality in the U.S. is attributable to within-tract differences (Galbraith and Hale 2008). In the case of exposure inequality, within-tract variation is likely to be less important, an expectation confirmed in our results.

To measure horizontal inequality, we partition households on the basis of income and demographic variables obtained from the American Community Survey (ACS), using five-year averages for the years 2006-2010. The census tract is the finest level of disaggregation available for these variables.

\section{Environmental inequality measures}

In this study we compare seven alternative measures of environmental inequality, calculated using the methods described in this section.

\subsection{Vertical inequality}

Measures of vertical inequality rank individuals on the basis of the variable of concern (here, pollution exposure) and then summarize the extent of differences among them.

\subsubsection{Gini coefficient}

The Gini coefficient is widely used to measure inequality in the distribution of income, expenditure and wealth (Dorfman 1979; Cowell 1995). We calculate the Gini coefficient for exposure by means of the following formula (using Stata's ineqdeco package):

$$
\text { Gini }=1+\left(\frac{1}{n}\right)-\left[\frac{2}{M E A N E X P * n^{2}}\right] \sum_{i=1}^{n}\left[(n-i+1) * E X P O S U R E_{i}\right]
$$


where EXPOSURE $E_{i}$ is industrial air toxics exposure in census tract (or grid cell) $i ; n=$ the number of tracts (or cells), indexed in non-decreasing order; and MEANEXP is the mean exposure for all tracts (or cells). The Gini coefficient lies in the interval between zero and one, with higher values denoting greater inequality.

While the Gini coefficient satisfies key properties of inequality measures (mean dependence, population size independence, symmetry, and Pigou-Dalton transfer sensitivity; see Haughton and Khandker 2009), it is more sensitive to changes in the middle of the distribution than to changes at the tails (Atkinson 1970; Duro 2012).

\subsubsection{Theil index and Generalized Entropy measure}

The Generalized Entropy (GE) family of inequality measures vary in their sensitivity to changes at different ranges of the distribution. The GE(1) measure, more commonly known as the Theil index, is most sensitive to the middle range, like the Gini coefficient. The Theil index is calculated as follows:

$$
\text { Theil }=\sum_{i=1}^{n}\left(\frac{w_{i}}{N}\right)\left(\frac{\text { EXPOSURE }_{i}}{\text { MEANEXP }}\right) \log \left(\frac{\text { EXPOSURE }_{i}}{\text { MEANEXP }}\right)
$$

where $w_{i}$ is the population weight for census tract $i$; and $N=\sum_{i=1}^{n} w i$.

We also calculate a second GE measure, GE(2), that is more sensitive to changes in the upper range of the distribution:

$$
G E(2)=\frac{1}{2} *\left[\left(\sum_{i=1}^{n}\left(\frac{w_{i}}{N}\right)\left(\frac{\operatorname{EXPOSURE} E_{i}}{\operatorname{MEANEXP}}\right)^{2}\right)-1\right]
$$

The values of GE measures in principle can range between zero and infinity, with a higher value again reflecting greater inequality.

\subsection{Horizontal inequality}

Measures of horizontal inequality partition the population into groups based on characteristics other than the variable of distributional concern, and then calculate between-group differences in the variable. Here we define groups on the basis of (i) race and ethnicity, distinguishing between Anglo whites and "minorities"; and (ii) income, distinguishing between households with incomes above and below the federal poverty 
line. Horizontal inequality along these axes is an explicit policy concern in U.S. federal and state environmental justice mandates. ${ }^{5}$

\subsubsection{Ratios of medians}

To compare exposures of racial and ethnic minorities to those of non-Hispanic whites (hereafter, simply "whites"), and to compare exposures of the poor to those of the nonpoor, we first calculate exposure levels for each population group:

$$
\text { EXPOSURE }_{j}=\sum_{i=1}^{n}\left(\text { EXPOSURE }_{i} * \operatorname{TOTALPOP}_{i} * X_{i j}\right) / \sum_{i=1}^{n}\left(\text { TOTALPOP }_{i} * X_{i j}\right)
$$

where subscript $j$ indexes the population group; and $X_{i j}$ is the share of group $j$ in the population of census tract $i$. This yields separate exposure distributions for each group.

Our first horizontal inequality measure is the ratio at the medians of the group exposure distributions: the minority/white median exposure ratio and the poor/nonpoor median exposure ratio.

\subsubsection{Ratios of $90^{\text {th }}$ percentiles}

Between-group exposure ratios may vary across the distributions, as illustrated in Figure 2. At the national level, the minority/white exposure ratio is fairly constant: across the two distributions, the exposures of minorities are roughly $50 \%$ above those of whites. The poor/nonpoor ratio, however, rises with the exposure percentiles. At the lower end of the distributions, the poor face less exposure than the nonpoor, perhaps reflecting their residence in locations with very low levels of industrial activity; but at the upper end, the exposures of the poor are roughly $50 \%$ higher than those of the nonpoor.

[insert Figure 2 here]

Because the distribution of industrial air pollution exposure is highly skewed - the top quintile of census tracts nationwide accounts for more than $80 \%$ of the total pollution

\footnotetext{
${ }^{5}$ Some authors have suggested that people may voluntarily choose to trade off environmental quality for higher incomes, such that those who live in more polluted locations (where they can earn higher incomes) are not worse off in terms of net welfare (Millimet and Slottje 2002). Others maintain that income and environmental quality are incommensurable, so the gains in the former cannot compensate for losses of the latter (Heinzerling and Ackerman 2005; Khaw et al. 2015). If horizontal inequality measurement shows that people with lower incomes generally face more pollution exposure, rather than less, the question of whether the two variables can offset each other becomes less relevant for welfare comparisons.
} 
load - horizontal inequality at the upper end of the distributions is of particular interest. To assess between-group inequalities in this range, we report the minority/white and poor/nonpoor ratios at the $90^{\text {th }}$ percentiles of exposure.

\section{Results}

This section applies the inequality measures described above to industrial air pollution exposure for U.S. states. In calculating Gini coefficients, we examine the effects of taking census tracts versus RSEI grid cells as the units of observation, and the impact of population weights on grid cell-based Ginis. We also compare Gini coefficients exposure inequality to those for income inequality. We then present the Theil index and the GE(2) measures to examine how sensitivity to different ranges of the distribution affects vertical inequality measures. Turning to horizontal inequality, we present the median and p90 exposure ratios to examine disparities between minorities and whites and between the poor and nonpoor. We then examine correlations between vertical and horizontal exposure inequality. Finally we examine correlation between exposure inequality and inter-state variations in exposure levels.

\subsection{Gini coefficients}

Three variants of the environmental Gini coefficient are reported in Table A.1. Those in the first column are based on tract-level data; those on the second column are based on unweighted grid cells; those in the third column are based on grid cells with population weights. ${ }^{6}$ For comparison, we also report Gini coefficients for income calculated from tract-level data and household-level data in the last two columns.

The results show high degrees of environmental inequality. The between-tract Gini is 0.76 at the national level, and it is 0.70 or higher in more than half of the states. The unweighted between-cell Gini is 0.93 at the national level, and it is higher than the between-tract Gini in almost all states. When we apply population weights to the calculation of between-cell Ginis, the results are nearly identical to the between-tract Ginis. This implies that intra-tract variations in exposure are minor compared to betweentract variation. The choice between census tracts and grid cells as a basis for computing exposure Ginis is therefore of little consequence if we are interested in inequality across the population rather than across areal units.

\footnotetext{
${ }^{6}$ Although each census tract contains approximately the same number of individuals, but not precisely the same number, we also apply population weights in calculating the tract-level Ginis reported here.
} 
The situation is quite different in the case of income Ginis. Comparing Ginis that we calculated on the basis of median tract income to Ginis calculated from household-level data by the U.S. Census Bureau (both based on 2010 ACS data), we find a marked difference between the two: the between-tract income Gini is 0.25 at the national level, compared to the household income Gini of 0.47 , and at the state level the differences between them often are larger. This reflects the existence of substantial intra-tract variations in incomes, consistent with the earlier findings of Galbraith and Hale (2008).

The Gini coefficient for exposure inequality is considerably higher than that for income inequality at the national level, and higher in all but two states. We can safely conclude on the basis of this evidence that exposure to industrial air toxics in the U.S. is more unequally distributed than income.

Table 1 presents Spearman rank correlations among the Gini coefficients. The betweentract exposure Gini and the population-weighted between-cell Gini are correlated almost perfectly, so hereafter we simply use tracts as the unit of analysis. The weak negative correlations between the Gini coefficients for exposure and income suggest that neither type of inequality can serve as a suitable proxy for the other.

[insert Table 1 here]

\subsection{Theil index and generalized entropy measures}

Table A.2 presents the Theil index and the GE(2) measures of vertical inequality, again calculated taking census tracts as the unit of analysis. In most cases the GE(2) measure is higher than the Theil index, indicating that greater sensitivity to exposure differences at the upper range of the distribution increases measured inequality.

Table 2 presents Spearman rank correlations for the tract-level Gini coefficient, the Theil index and the GE(2) measure. All three measures of vertical inequality are positively correlated. The correlation between the Gini coefficient and the Theil index is close to one, consistent with their sensitivity to differences in the middle range of the distribution.

[insert Table 2 here]

\subsection{Horizontal inequality: median exposure ratios}

Table A.3 presents our horizontal inequality measures. Nationwide, the minority/white median exposure ratio is 1.46. Horizontal income inequality between whites and minorities is roughly comparable in magnitude: the ratio of their median household 
incomes in 2010 was 1.4. ${ }^{7}$ The median exposure ratio is less than one in only ten states, and less than 0.67 only in the Dakotas and Montana, where Native Americans, many of whom reside far from industrial facilities, comprise the largest minority. In six states Arkansas, California, Kentucky, Michigan, Minnesota and Wisconsin - median minority exposure is more than three times greater than median white exposure.

The poor/nonpoor median exposure ratio nationwide is 1.11. Among the states it ranges from 0.35 in Idaho to 3.59 in Wyoming. This measure reflects the balance between two opposing effects. On the one hand, insofar as the presence of industry is correlated with higher incomes as well as higher pollution, the exposure of the poor would be expected to be less than that of the nonpoor, yielding a ratio smaller than one. On the other hand, insofar as more polluting facilities tend to be located in greater proximity to the lowerincome neighborhoods within industrialized areas, this would yield a ratio greater than one. Their net effect appears to vary considerably from state to state. The ratio is less than 0.8 in nine states. It is above one in 26 states - and above three in Virginia and Wyoming - again indicating that higher pollution exposure often is not compensated by higher incomes.

\subsection{Horizontal inequality: $90^{\text {th }}$ percentile exposure ratios}

Comparisons at the $90^{\text {th }}$ percentiles for each group yield a minority/white exposure ratio of 1.41 and a poor/nonpoor exposure ratio of 1.33. The range of variation among states in the $90^{\text {th }}$ percentile ratios is somewhat narrower than in the median ratios. Four states (Arkansas, Georgia, Illinois and Kentucky) have minority/white p90 ratios above 2.0, two (Virginia and Missouri) have poor/nonpoor p90 ratios above 2.0.

\subsection{Correlations among exposure inequality measures}

Table 3 presents Spearman rank correlation coefficients for the four horizontal inequality measures and the Gini and GE(2) measures of vertical inequality. In general, the correlations amongst them are fairly low, implying that inter-state rankings of environmental inequality can be quite sensitive to the choice of a measure. The strongest positive correlations are between the two measures of vertical inequality (0.82) and between the two measures of minority/white inequality (0.54). Correlations across measures of the two dimensions of horizontal inequality - the minority/white and poor/nonpoor ratios - are also positive, but not as strong.

[insert Table 3 here]

${ }^{7}$ Calculated from DeNavas-Walt et al. (2011), Table A-1, "Income and Earnings Summary Measures by Selected Characteristics: 2007 and 2010." 
The correlations between vertical and horizontal inequality measures are weak, and in many cases they are negative. One might have expected, a priori, that states with greater vertical inequality - that is, a wider range of exposure across the entire population would also tend to show greater horizontal inequalities between groups defined on the basis of minority status or income. To illustrate that this is not necessarily true, in Figure 3 we compare the percentile-wise exposures for minorities and whites in two states, Ohio and Virginia. Ohio has a relatively low Gini and relatively high minority/white median ratios, while Virginia has the opposite. The contrast implies that multiple measures of exposure inequality are necessary to capture its different dimensions. ${ }^{8}$

[insert Figure 3 here]

\subsection{Correlations between levels and inequality}

Table 4 presents correlations between our exposure inequality measures and exposure levels at the median and the $90^{\text {th }}$ percentile of the state's distribution. ${ }^{9}$ The negative correlations between exposure levels and vertical inequality mean that industrial air pollution exposure tends to be distributed more unequally in states with less of it. This reflects the fact that some states (for example, Alaska and Vermont) have very low exposure levels in most tracts but substantial exposure levels in a few.

[insert Table 4 here]

Minority/white exposure ratios, on the other hand, are positively correlated with exposure levels; that is, pollution exposure tends to be higher in states where it is more strongly concentrated in minority communities. This is consistent with the previous finding that in U.S. metropolitan areas with greater minority/white pollution exposure discrepancies, whites as well as minorities have higher exposures than in metropolitan areas with smaller discrepancies (Ash et al. 2013). Causal explanations for this relationship could run in either or both directions: environmental regulation may tend to be weaker in states where pollution burdens fall more heavily on minorities, and there may be a greater tendency to shift pollution burdens onto minority communities in states

\footnotetext{
${ }^{8}$ Two further features of Figure 3 deserve comment. First, more than 15\% of Ohio's minority population lives in census tracts with exposure at or above the $97^{\text {th }}$ national percentile (the level at which our exposure data are censored, flattening the curve). Second, the most exposed decile of whites in Virginia faces considerably higher exposure than the most exposed decile of minorities. As noted above, Virginia's poor/nonpoor median and p90 exposure ratios are above 3.0; taken together, these observations indicate disproportionately high exposures among poor whites in the state.

${ }^{9}$ Median and $90^{\text {th }}$ percentile exposure levels are reported in the supplementary material that accompanies this paper.
} 
with more pollution. Both explanations suggest that racial and ethnic disparities in political power can have important consequences for state environmental policies.

\section{Policy implications and avenues for future research}

This analysis of the distribution of industrial air pollution exposure in the U.S. demonstrates the multi-dimensionality of environmental inequality. Comparing a number of alternative measures of vertical and horizontal (between-group) we find that these can often yield quite different inter-state rankings of environmental inequalities.

Comparing vertical inequality in the distribution of exposure to that in the distribution of income, we find much greater inequality in exposure. At the national level, the Gini coefficient for exposure in 2010 was 0.76 , well above the Gini coefficient for income. Vertical inequality in the distribution of exposure is a matter of concern if one accepts the normative principle that every person has an equal right to a clean and safe environment. Of course, the extent to which pollution exposures exceed levels judged to be "safe" is also important. Even in those states where the median exposure is relatively low, however, measures of vertical inequality can be of interest to assess the possibility that average measures may mask serious environmental risks in specific communities.

Environmental inequalities may be considered especially objectionable when those who face disproportionate harms are also disadvantaged in other respects. Environmental justice policies in the U.S. seek to remedy and prevent disproportionately environmental health impacts on minorities and low-income communities. For such policies, measures of horizontal inequality are of particular relevance.

When the distribution of environmental harm is highly skewed, as in the case of exposure to industrial air pollution, it is important to employ inequality measures that are sensitive to differences in the upper range of the distribution. To measure vertical inequality, the GE(2) measure may be preferable in this respect to the Gini coefficient or Theil index. To measure horizontal inequality, exposure ratios at the $90^{\text {th }}$ percentile of the distributions may be preferable to exposure ratios at the medians.

However it is measured, inequality is only one of several relevant criteria for assessing environmental policy outcomes. No one would claim that social welfare would be improved by increasing pollution exposure in all census tracts until it equals that in the most exposed one, notwithstanding the fact that this would be one way to eliminate exposure inequality. But in deciding where to allow new pollution sources to be sited, or where prioritize abatement and enforcement efforts among existing sources, impacts on environmental inequality may be a relevant policy criterion. The development of 
inequality measures to assist in the pursuit and evaluation of this objective can help to counter complacency about the existence of "sacrifice zones," communities burdened by exceptionally high pollution loads, and can help to catalyze greater attention among researchers and the public to the distribution of environmental quality.

Further research is needed to develop comparable measures for other types of environmental inequality, including exposure to mobile-source air pollution and to water pollution. Among other things, this will allow researchers to investigate whether variations in these aspects of environmental inequality are correlated with the variations in exposure inequality reported here. There is also scope for measuring and analyzing environmental inequality at other spatial scales, such as within metropolitan areas. Finally, measurement of environmental inequality creates possibilities for researchers to analyze its relationship to other variables of interest to social scientists and policy makers, such as residential segregation, voting behavior and state environmental policies.

\section{Appendix}

[insert Tables A.1 to A.3 here]

\section{References}

Anderson, R J, Crocker, T D, 1971, “Air Pollution and Residential Property Values,” Urban Studies 8(3) 171-180.

Ash, M, Fetter, T R, 2004, "Who Lives on the Wrong Side of the Environmental Tracks?” Social Science Quarterly 85(2) 441-462.

Ash, M, Boyce, J K, Chang, G, Scharber, H, 2013, "Is Environmental Justice Good for White Folks? Industrial Air Toxics Exposure in Urban America," Social Science Quarterly 94(3) 616-636.

Atkinson, A B, 1970, “On the measurement of inequality,” Journal of Economic Theory 2(3) 244-263.

Barros, R P, Ferreira, F H G, Molinas Vega, J R, Saaverda Chanduvi, J, 2009, Measuring Inequality of Opportunities in Latin America and the Caribbean. World Bank, Washington, DC.

Bonorris, S, ed, 2010, Environmental Justice for All: A Fifty State Survey of Legislation, Policies and Cases, $4^{\text {th }}$ edn. Berkeley, CA: American Bar Association and Hastings College of the Law, University of California. 
Boyce, J K, Pastor, M, 2012, "Cooling the Planet, Clearing the Air: Climate Policy, Carbon Pricing, and Co-Benefits.” Economics for Equity and the Environment, Portland, OR.

Bouvier, R, 2014, “Inequality in Two Dimensions: An Analysis of the Distribution of Income and Toxic Emissions in Maine,” Ecological Economics 102 39-47.

Brender, J D, Maantay, J A, and Chakraborty, J, 2011, "Residential Proximity to Environmental Hazards and Adverse Health Outcomes," American Journal of Public Health 101(S1) 37-52.

Brueckner, J, and Rosenthal, S, 2009, “Gentrification and neighborhood housing cycles: Will America's future downtowns be rich?” Review of Economics and Statistics 91(4) 725-743.

Bullard, R D, Johnson, G S, Torres, A O, 2011, Environmental Health and Racial Equity in the United States: Building Environmentally Just, Sustainable, and Livable Communities. American Public Health Association, Washington, DC.

Chay, K Y, Greenstone, M, 2003, "The Impact of Air Pollution on Infant Mortality: Evidence from Geographic Variation in Pollution Shocks Induced by a Recession,” Quarterly Journal of Economics 118(3) 1121-1167.

Chay, K Y, Greenstone, M, 2005, “Does Air Quality Matter? Evidence from the Housing Market,” Journal of Political Economy 113(2) 376-424.

Cowell, F., 1995. Measuring Inequality. New York: Prentice Hall.

Currie, J, 2011, “Inequality at Birth,” American Economic Review Papers \& Proceedings 101(3) 1-22.

Currie, J, Davis, L, Greenstone, M, Walker, R, 2015, “Environmental Health Risks and Housing Values: Evidence from 1,600 Toxic Plant Openings and Closings,” American Economic Review 105(2) 678-709.

Currie, J, Neidell, M, 2005, “Air Pollution and Infant Health: What Can We Learn from California's Recent Experience?” Quarterly Journal of Economics 120(3) 1003-1030.

Currie, J, Hanushek, E A, Kahn, E M, Neidell, M, Rivkin, S G, 2009, “Does pollution increase school absences?” Review of Economics and Statistics 91(4) 682-694.

Currie, J, Neidell, M, and Schmeider, J F, 2009, “Air Pollution and Infant Health: Lessons from New Jersey,” Journal of Health Economics 28 688-703. 
DeNavas-Walt, C, Proctor, B D, Smith, J C, 2011, "Income, Poverty and Health Insurance Coverage in the United States: 2010," Washington, DC: U.S. Census Bureau, Current Population Reports.

Dorfman, R, 1979, “A Formula for the Gini Coefficient”, The Review of Economics and Statistics, 61(1) 146-149.

Downey, L, 2007, "U.S. Metropolitan-area Variation in Environmental Inequality Outcomes," Urban Studies 44 953-977.

Druckman, A, Jackson, T, 2008, "Measuring Resource Inequalities: The concepts and methodology for an area-based Gini coefficient,” Ecological Economics 65 242-252.

Duro, J A, 2012, "On the automatic application of inequality indexes in the analysis of the international distribution of environmental indicators", Ecological Economics 76 1-7.

Evans, G W, Kantrowitz, E, 2002, "Socioeconomic Status and Health: The Potential Role of Environmental Risk Exposure,” Annual Review of Public Health 23 303-331.

Fann, N, Fulcher, C M, Baker, K, 2013, "The Recent and Future Health Burden of Air Pollution Apportioned Across U.S. Sectors,” Environmental Science \& Technology 47(8) 3580-89.

Galbraith, J K, Hale, J T, 2008, "State Income Inequality and Presidential Election Turnout and Outcomes,” Social Science Quarterly 89(4) 887-901.

Grandjean, P, Landrigan, P J, 2014, "Neurobehavioural effects of developmental toxicity,” Lancet Neurology 13(3) 330-338.

Graff Zivin, J, Neidell M, 2012, "The Impact of Pollution on Worker Productivity," American Economic Review, 102(7) 3652-73.

Haughton, J H, Khandker, S R, 2009, Handbook on poverty and inequality. World Bank Publications.

Heil, M T, Wodon, Q T, 2000, "Future Inequality in CO2 Emissions and the Impact of Abatement Proposals,” Environment and Resource Economics 17 163-181.

Heinzerling, L, Ackerman, F, 2005, Priceless: On Knowing the Price of Everything and the Value of Nothing. New York: New Press.

Khaw, M W, Grab, D A, Livermore, M A, Vossler, C A, Glimcher, P W, 2015, "The Measurement of Subjective Value and Its Relation to Contingent Valuation and Environmental Public Goods," PLoS ONE 10(7): e0132842.

doi:10.1371/journal.pone.0132842. 
Lavy, V, Ebenstein, A, Roth, S, 2014, "The long-run human and economic consequences of high-stakes examinations," WP 20647, National Bureau of Economic Research, Cambridge, MA.

Lucier, C, Rosofsky, A, London, B, Scharber, H, Shandra, J M, 2011, “Toxic pollution and school performance scores: Environmental ascription in East Baton Rouge Parish, Louisiana," Organization \& Environment 24(4) 423-443.

Maantay, J, 2007, "Asthma and air pollution in the Bronx: Methodological and data considerations in using GIS for environmental justice and health research," Health \& Place 13 32-56.

Meltz, R, 1999, "Right to a Clean Environment Provisions in State Constitutions, and Arguments as to a Federal Counterpart," Congressional Research Service, Report for Congress, Washington, DC, February 23.

Millimet, D L, Slottje, D, 2002, “An environmental Paglin-Gini,” Applied Economics Letters 9 271-274.

Mohai, P, 2008, "Equity and the Environmental Justice Debate," in Equity and the Environment, Eds R C Wilkinson and W R Freudenberg, Research in Social Problems and Public Policy, Vol. 15 (Elsevier, Amsterdam) pp. 21-50.

Mohai, P. Kweon, B-S, Lee, S, \& Ard, K, 2011, "Air pollution around schools is linked to poorer student health and academic performance," Health Affairs 30(5) 852-862.

Morello-Frosch, R, Zuk, M, Jerrett, M, Shamasunder, B, Kyle, A D, 2011, "Understanding the Cumulative Impacts of Inequalities in Environmental Health: Implications for Policy,” Health Affairs 30(5) 879-887.

Obama, B, 2014, "Presidential Proclamation -- 20th Anniversary of Executive Order 12898 on Environmental Justice." Office of the Press Secretary, White House, Washington, DC, February 10.

Pastor, M, Sadd, J, Morello-Frosch, R, 2002, "Who's Minding the Kids? Pollution, Public Schools, and Environmental Justice in Los Angeles," Social Science Quarterly 83(1) 263-280.

Pastor, M, Jr., Sadd, J, Morello-Frosch, R. 2004, "Reading, writing and toxics: children’s health, academic performance, and environmental justice in Los Angeles," Environment and Planning C: Government and Policy 22 271-290.

Pedersen, M, et al., 2013, "Ambient air pollution and low birthweight: a European cohort study (ESCAPE)," Lancet Respiratory Medicine 1(9) 695-704. 
Popovic, N.A.F., 1996, "In pursuit of environmental human rights," Columbia Human Rights Law Review 27 487-620.

Richter, F, and Craig, B R, 2013, "Lending patterns in poor neighborhoods," Journal of Economic Behavior \& Organization 95 197-206.

Szasz, A, Meuser, M, 1997, "Environmental Inequalities: Literature Review and Proposals for New Directions in Research and Theory," Current Sociology, 45(3) 99-120.

Topa, G, 2001, "Social Interactions, Local Spillovers and Unemployment," Review of Economic Studies 68(235) 261-295.

U.S. Environmental Protection Agency (EPA), 2014, "Mercury and Air Toxics Standards (MATS): Healthier Americans,” http://www.epa.gov/mats/health.html. Accessed 9 February 2015.

World Health Organization, 2014, "7 million premature deaths annually linked to air pollution," http://www.who.int/mediacentre/news/releases/2014/air-pollution/en/. Accessed 23 February 2015.

Zwickl, K, Ash, M, and Boyce, J K, 2014, "Regional Variation in Environmental Inequality: Industrial Air Toxics exposure in U.S. cities," Ecological Economics 107 494-509.

Zwickl, K, and Moser, M, 2014, "Informal environmental regulation of industrial air pollution: Does neighborhood inequality matter?” Political Economy Research Institute, Amherst, MA, Working Paper 370. 
Table 1: Gini coefficients: Spearman rank correlations

\begin{tabular}{|c|c|c|c|c|c|}
\hline & $\begin{array}{c}\text { Between-tract } \\
\text { exposure } \\
\text { Gini }\end{array}$ & $\begin{array}{l}\text { Between- cell } \\
\text { exposure Gini } \\
\text { (unweighted) }\end{array}$ & $\begin{array}{l}\text { Between-cell } \\
\text { exposure Gini } \\
\text { (population- } \\
\text { weighted) }\end{array}$ & $\begin{array}{l}\text { Between-tract } \\
\text { income Gini }\end{array}$ & $\begin{array}{l}\text { Individual } \\
\text { income } \\
\text { Gini }\end{array}$ \\
\hline \multicolumn{6}{|l|}{ Between-tract exposure } \\
\hline Gini & 1.00 & & & & \\
\hline $\begin{array}{l}\text { Between-cell exposure Gini } \\
\text { (unweighted) }\end{array}$ & 0.58 & 1.00 & & & \\
\hline $\begin{array}{l}\text { Between-cell exposure Gini } \\
\text { (population weighted) }\end{array}$ & 1.00 & 0.59 & 1.00 & & \\
\hline $\begin{array}{l}\text { Between-tract } \\
\text { income Gini }\end{array}$ & -0.26 & -0.24 & -0.29 & 1.00 & \\
\hline Individual income Gini & -0.21 & -0.43 & -0.23 & 0.78 & 1.00 \\
\hline
\end{tabular}

Table 2: Three measures of vertical inequality: Spearman rank correlations

$\begin{array}{lccc} & \text { Gini } & \text { Theil index } & \text { GE(2) } \\ \text { Gini } & 1.00 & & \\ \text { Theil index } & 0.98 & 1.00 & \\ \text { GE(2) } & 0.82 & 0.92 & 1.00\end{array}$


Table 3: Horizontal and vertical inequality: Spearman rank correlations

$\begin{array}{lcccccc} & \text { Gini } & \text { GE(2) } & \begin{array}{c}\text { Minority/ } \\ \text { white } \\ \text { median }\end{array} & \begin{array}{c}\text { Minority/ } \\ \text { white } \\ \text { p90 }\end{array} & \begin{array}{c}\text { Poor/ } \\ \text { nonpoor } \\ \text { median }\end{array} & \begin{array}{c}\text { Poor/ } \\ \text { nonpoor } \\ \text { p90 }\end{array} \\ \text { Gini } & 1.00 & & & & & \\ \text { GE(2) } & 0.82 & 1.00 & & & & \\ \text { Minority/white median } & -0.32 & -0.37 & 1.00 & & & \\ \text { Minority/white p90 } & -0.15 & -0.28 & 0.54 & 1.00 & & \\ \text { Poor/nonpoor median } & -0.24 & -0.13 & 0.42 & 0.06 & 1.00 & \\ \text { Poor/nonpoor p90 } & 0.13 & 0.03 & 0.31 & 0.49 & 0.33 & 1.00\end{array}$

Table 4: Exposure levels and exposure inequality: Spearman rank correlations

$\begin{array}{lcc} & \text { Median exposure } & \text { p90 exposure } \\ \text { Gini } & -0.65 & -0.29 \\ \text { GE(2) } & -0.77 & -0.60 \\ \text { Minority/white median } & 0.47 & 0.38 \\ \text { Minority/white p90 } & 0.36 & 0.38 \\ \text { Poor/nonpoor median } & 0.07 & -0.07 \\ \text { Poor/nonpoor p90 } & 0.18 & 0.23 \\ \text { Median exposure } & 1.00 & 0.86\end{array}$


Figure 1a: Industrial air toxics exposure by state
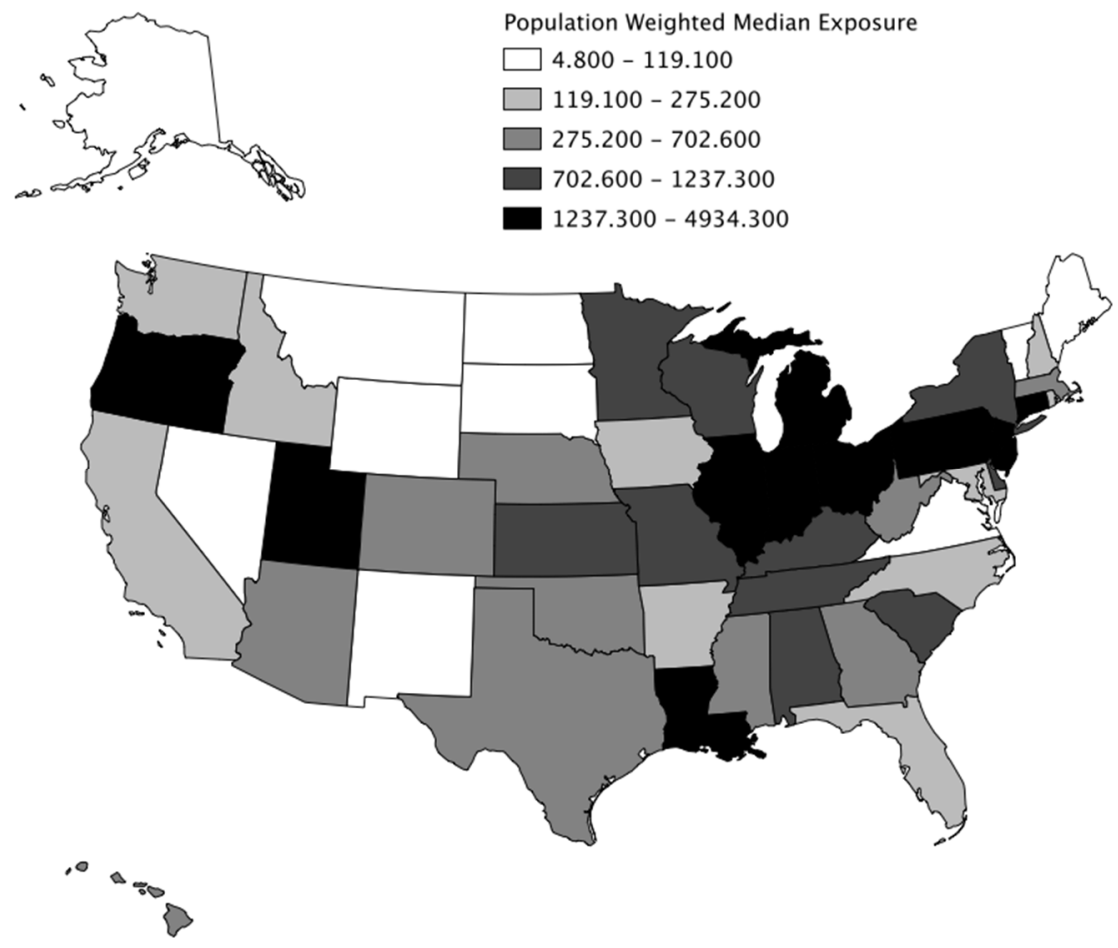

Figure 1b: Industrial air toxics exposure by census tract

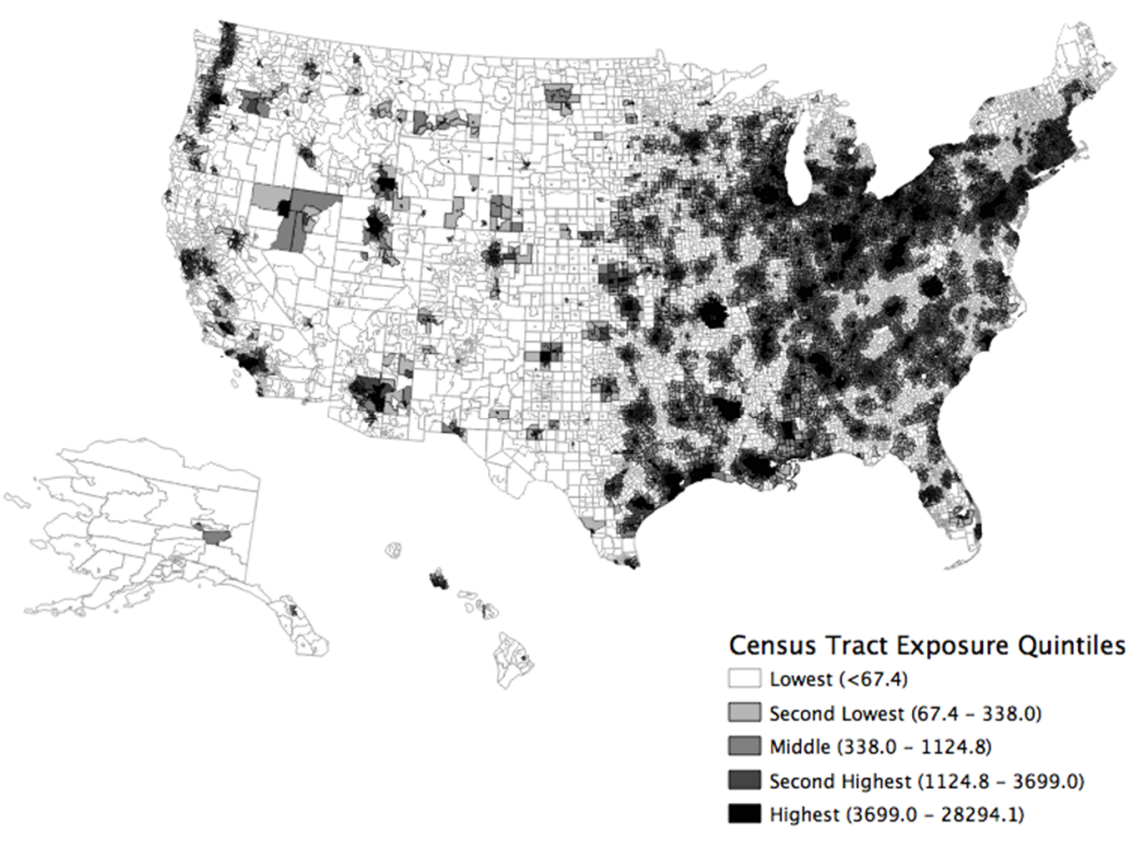


Figure 2: Horizontal inequality ratios by exposure percentile

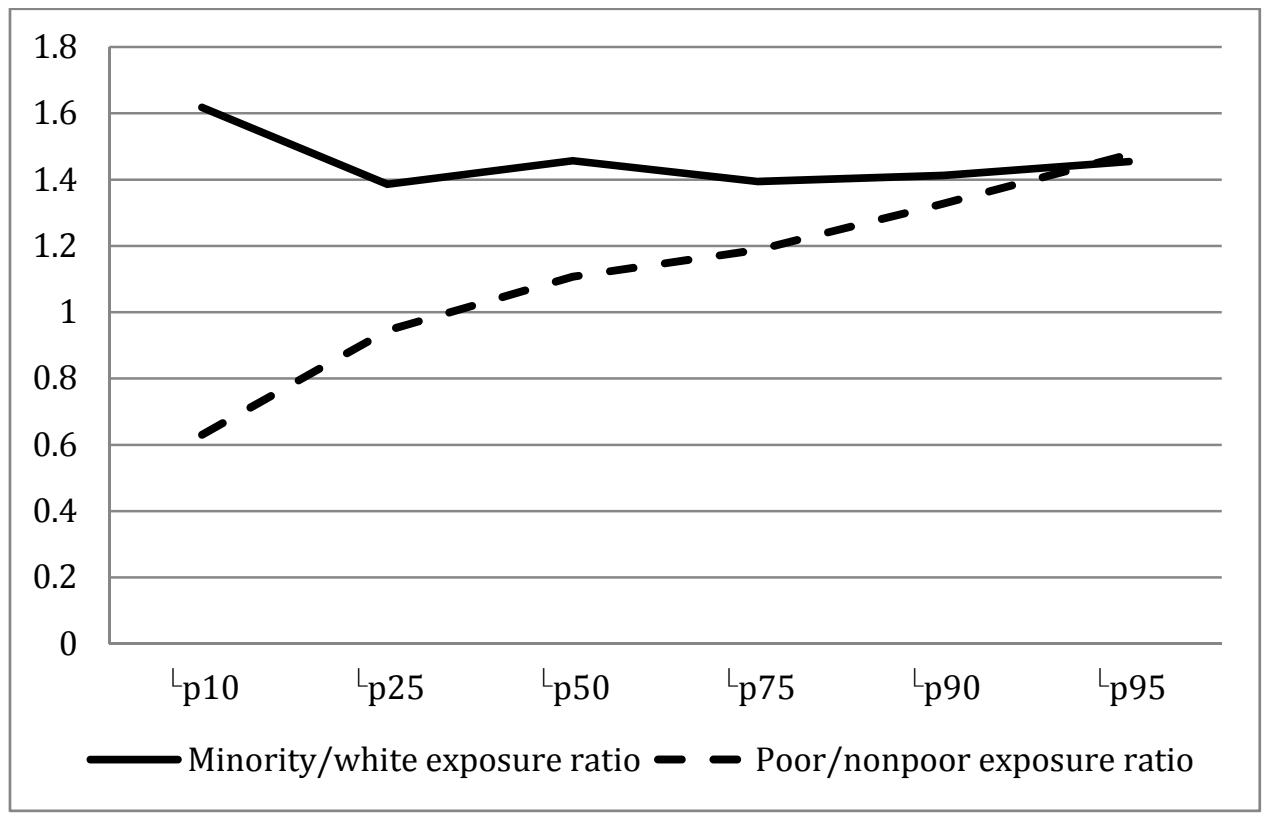


Figure 3: Minority and white exposure by percentile: Ohio and Virginia

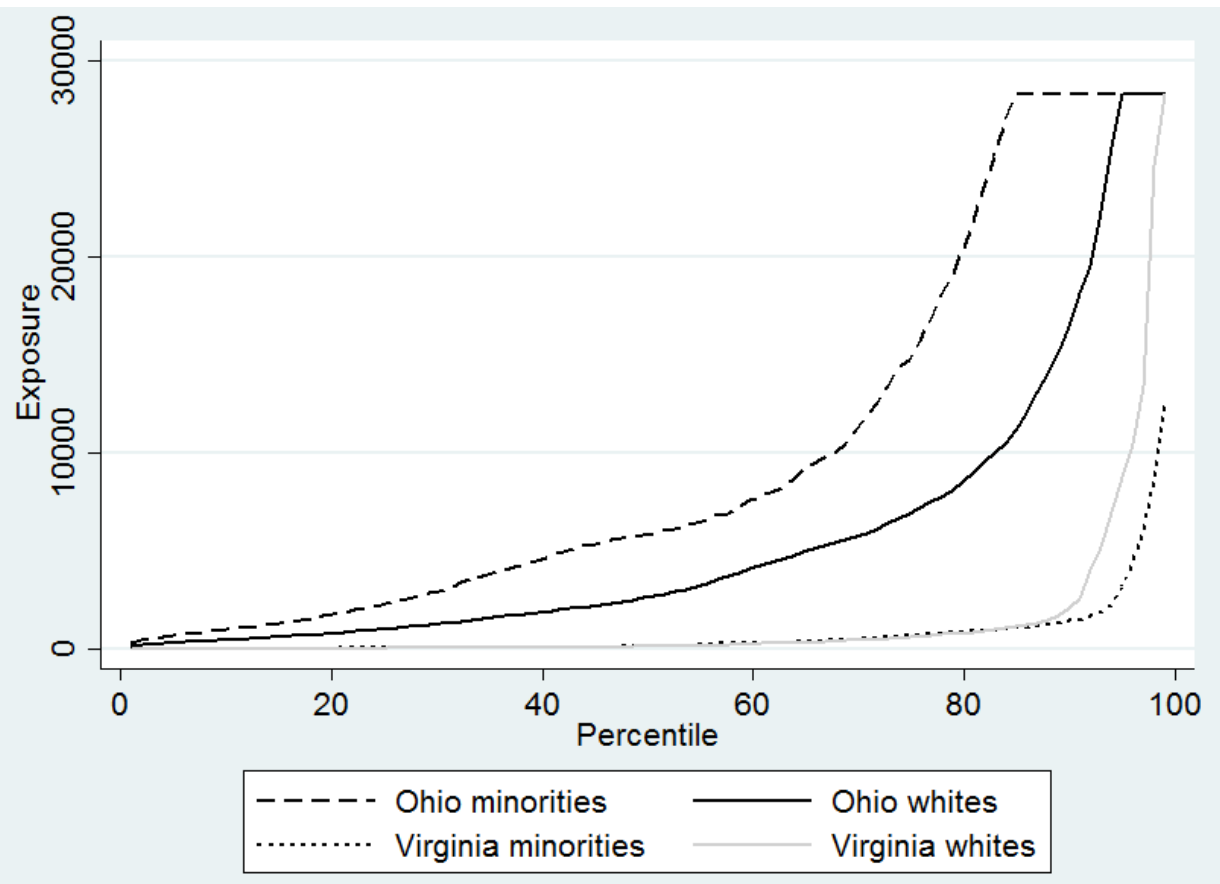




\section{Table A.1: Gini coefficients for exposure and income}

Exposure

\begin{tabular}{ccc}
\hline $\begin{array}{c}\text { Between- } \\
\text { tract }\end{array}$ & $\begin{array}{c}\text { Between-cell, } \\
\text { unweighted }\end{array}$ & $\begin{array}{c}\text { Between-cell, } \\
\text { population- } \\
\text { weighted }\end{array}$
\end{tabular}

Income

Between- Individual
tract

\begin{tabular}{|c|c|c|c|c|c|}
\hline Alabama & 0.73 & 0.80 & 0.73 & 0.21 & 0.47 \\
\hline Alaska & 0.91 & 1.00 & 0.92 & 0.17 & 0.42 \\
\hline Arizona & 0.76 & 0.96 & 0.75 & 0.26 & 0.46 \\
\hline Arkansas & 0.81 & 0.87 & 0.81 & 0.18 & 0.46 \\
\hline California & 0.80 & 0.96 & 0.79 & 0.29 & 0.47 \\
\hline Colorado & 0.71 & 0.95 & 0.71 & 0.22 & 0.46 \\
\hline Connecticut & 0.61 & 0.60 & 0.60 & 0.25 & 0.49 \\
\hline Delaware & 0.48 & 0.70 & 0.49 & 0.20 & 0.44 \\
\hline DC & 0.34 & 0.38 & 0.35 & 0.33 & 0.53 \\
\hline Florida & 0.72 & 0.78 & 0.71 & 0.24 & 0.47 \\
\hline Georgia & 0.70 & 0.76 & 0.69 & 0.23 & 0.47 \\
\hline Hawaii & 0.53 & 0.92 & 0.55 & 0.18 & 0.43 \\
\hline Idaho & 0.81 & 0.97 & 0.81 & 0.16 & 0.43 \\
\hline Illinois & 0.60 & 0.81 & 0.59 & 0.25 & 0.47 \\
\hline Indiana & 0.65 & 0.73 & 0.65 & 0.18 & 0.44 \\
\hline Iowa & 0.82 & 0.77 & 0.82 & 0.15 & 0.43 \\
\hline Kansas & 0.74 & 0.91 & 0.73 & 0.21 & 0.45 \\
\hline Kentucky & 0.71 & 0.77 & 0.70 & 0.20 & 0.47 \\
\hline Louisiana & 0.65 & 0.83 & 0.64 & 0.21 & 0.48 \\
\hline Maine & 0.77 & 0.86 & 0.77 & 0.14 & 0.44 \\
\hline Maryland & 0.69 & 0.75 & 0.69 & 0.22 & 0.44 \\
\hline Massachusetts & 0.63 & 0.70 & 0.63 & 0.21 & 0.48 \\
\hline Michigan & 0.68 & 0.90 & 0.68 & 0.21 & 0.45 \\
\hline Minnesota & 0.69 & 0.92 & 0.68 & 0.19 & 0.44 \\
\hline Mississippi & 0.82 & 0.85 & 0.81 & 0.19 & 0.47 \\
\hline Missouri & 0.77 & 0.90 & 0.76 & 0.20 & 0.46 \\
\hline Montana & 0.83 & 0.96 & 0.85 & 0.14 & 0.44 \\
\hline Nebraska & 0.67 & 0.85 & 0.66 & 0.18 & 0.43 \\
\hline Nevada & 0.85 & 0.97 & 0.85 & 0.22 & 0.45 \\
\hline New Hampshire & 0.63 & 0.85 & 0.61 & 0.14 & 0.43 \\
\hline New Jersey & 0.61 & 0.73 & 0.60 & 0.23 & 0.46 \\
\hline New Mexico & 0.80 & 0.97 & 0.81 & 0.23 & 0.46 \\
\hline New York & 0.59 & 0.82 & 0.58 & 0.29 & 0.50 \\
\hline North Carolina & 0.79 & 0.81 & 0.78 & 0.21 & 0.46 \\
\hline North Dakota & 0.77 & 0.94 & 0.79 & 0.13 & 0.43 \\
\hline Ohio & 0.59 & 0.68 & 0.58 & 0.20 & 0.45 \\
\hline Oklahoma & 0.76 & 0.88 & 0.75 & 0.20 & 0.45 \\
\hline Oregon & 0.64 & 0.95 & 0.64 & 0.18 & 0.45 \\
\hline Pennsylvania & 0.59 & 0.70 & 0.58 & 0.22 & 0.46 \\
\hline Rhode Island & 0.32 & 0.38 & 0.34 & 0.20 & 0.47 \\
\hline South Carolina & 0.71 & 0.72 & 0.70 & 0.21 & 0.46 \\
\hline
\end{tabular}




$\begin{array}{llllll}\text { South Dakota } & 0.86 & 0.92 & 0.87 & 0.17 & 0.44 \\ \text { Tennessee } & 0.67 & 0.75 & 0.66 & 0.22 & 0.47 \\ \text { Texas } & 0.75 & 0.93 & 0.75 & 0.28 & 0.47 \\ \text { Utah } & 0.58 & 0.97 & 0.57 & 0.17 & 0.42 \\ \text { Vermont } & 0.84 & 0.87 & 0.86 & 0.13 & 0.44 \\ \text { Virginia } & 0.85 & 0.88 & 0.85 & 0.24 & 0.46 \\ \text { Washington } & 0.72 & 0.91 & 0.73 & 0.21 & 0.44 \\ \text { West Virginia } & 0.76 & 0.83 & 0.75 & 0.15 & 0.45 \\ \text { Wisconsin } & 0.65 & 0.80 & 0.65 & 0.17 & 0.43 \\ \text { Wyoming } & 0.78 & 0.93 & 0.82 & 0.13 & 0.42 \\ \text { National } & \mathbf{0 . 7 6} & \mathbf{0 . 9 3} & \mathbf{0 . 7 6} & \mathbf{0 . 2 5} & \mathbf{0 . 4 7}\end{array}$


Table A.2: Generalized entropy measures of exposure inequality

\begin{tabular}{|c|c|c|}
\hline & Theil index & $\mathrm{GE}(2)$ \\
\hline Alabama & 1.05 & 1.80 \\
\hline Alaska & 2.34 & 9.84 \\
\hline Arizona & 1.27 & 3.37 \\
\hline Arkansas & 1.43 & 3.29 \\
\hline California & 1.30 & 2.25 \\
\hline Colorado & 0.98 & 1.85 \\
\hline Connecticut & 0.73 & 1.23 \\
\hline Delaware & 0.43 & 0.62 \\
\hline DC & 0.33 & 0.85 \\
\hline Florida & 1.18 & 3.77 \\
\hline Georgia & 1.09 & 2.80 \\
\hline Hawaii & 0.53 & 0.76 \\
\hline Idaho & 1.52 & 4.05 \\
\hline Illinois & 0.62 & 0.74 \\
\hline Indiana & 0.80 & 1.24 \\
\hline Iowa & 1.48 & 3.19 \\
\hline Kansas & 1.06 & 1.36 \\
\hline Kentucky & 0.94 & 1.33 \\
\hline Louisiana & 0.75 & 0.84 \\
\hline Maine & 1.40 & 5.91 \\
\hline Maryland & 1.14 & 4.51 \\
\hline Massachusetts & 0.93 & 2.69 \\
\hline Michigan & 0.89 & 1.42 \\
\hline Minnesota & 0.92 & 1.48 \\
\hline Mississippi & 1.53 & 3.79 \\
\hline Missouri & 1.29 & 2.50 \\
\hline Montana & 1.54 & 3.42 \\
\hline Nebraska & 1.02 & 2.82 \\
\hline Nevada & 2.03 & 10.50 \\
\hline New Hampshire & 0.95 & 3.29 \\
\hline New Jersey & 0.70 & 1.08 \\
\hline New Mexico & 1.61 & 11.12 \\
\hline New York & 0.73 & 1.54 \\
\hline North Carolina & 1.58 & 5.83 \\
\hline North Dakota & 1.21 & 2.11 \\
\hline Ohio & 0.61 & 0.76 \\
\hline Oklahoma & 1.21 & 2.60 \\
\hline Oregon & 0.75 & 0.83 \\
\hline Pennsylvania & 0.63 & 0.85 \\
\hline Rhode Island & 0.17 & 0.20 \\
\hline South Carolina & 0.98 & 1.64 \\
\hline South Dakota & 1.83 & 5.79 \\
\hline Tennessee & 0.90 & 1.67 \\
\hline Texas & 1.11 & 1.61 \\
\hline
\end{tabular}




$\begin{array}{lll}\text { Utah } & 0.61 & 0.65 \\ \text { Vermont } & 1.68 & 4.53 \\ \text { Virginia } & 1.78 & 5.26 \\ \text { Washington } & 1.17 & 3.39 \\ \text { West Virginia } & 1.11 & 1.53 \\ \text { Wisconsin } & 0.77 & 1.11 \\ \text { Wyoming } & 1.24 & 2.03 \\ \text { National } & \mathbf{1 . 1 6} & \mathbf{1 . 9 8}\end{array}$


Table A.3: Horizontal measures of exposure inequality

\begin{tabular}{|c|c|c|c|c|}
\hline & $\begin{array}{l}\text { Minority/white } \\
\text { median exposure } \\
\text { ratio }\end{array}$ & $\begin{array}{l}\text { Minority/white } \\
\text { p90 exposure } \\
\text { ratio }\end{array}$ & $\begin{array}{c}\text { Poor/nonpoor } \\
\text { median exposure } \\
\text { ratio }\end{array}$ & $\begin{array}{c}\text { Poor/nonpoor } \\
\text { p90 exposure } \\
\text { ratio }\end{array}$ \\
\hline Alabama & 0.94 & 1.38 & 0.86 & 1.28 \\
\hline Alaska & 1.00 & 0.73 & 0.89 & 0.77 \\
\hline Arizona & 1.10 & 1.03 & 1.07 & 1.26 \\
\hline Arkansas & 3.24 & 3.34 & 1.02 & 1.77 \\
\hline California & 3.48 & 1.79 & 1.25 & 0.96 \\
\hline Colorado & 1.76 & 1.35 & 1.32 & 1.34 \\
\hline Connecticut & 1.06 & 1.36 & 1.17 & 1.62 \\
\hline Delaware & 1.36 & 1.26 & 1.07 & 0.89 \\
\hline DC & 1.13 & 1.07 & 0.96 & 0.94 \\
\hline Florida & 1.88 & 1.81 & 1.19 & 1.22 \\
\hline Georgia & 1.89 & 2.05 & 0.94 & 1.48 \\
\hline Hawaii & 2.02 & 1.41 & 1.12 & 0.94 \\
\hline Idaho & 1.05 & 1.77 & 0.35 & 1.45 \\
\hline Illinois & 2.92 & 2.33 & 1.73 & 1.67 \\
\hline Indiana & 2.01 & 1.35 & 1.36 & 1.59 \\
\hline Iowa & 1.22 & 1.30 & 1.19 & 1.47 \\
\hline Kansas & 2.20 & 1.29 & 0.57 & 1.25 \\
\hline Kentucky & 3.66 & 2.72 & 0.50 & 1.74 \\
\hline Louisiana & 1.76 & 1.24 & 0.84 & 1.06 \\
\hline Maine & 1.45 & 1.23 & 0.95 & 1.07 \\
\hline Maryland & 0.67 & 0.55 & 1.80 & 1.26 \\
\hline Massachusetts & 1.05 & 1.13 & 1.10 & 1.16 \\
\hline Michigan & 3.10 & 1.60 & 1.28 & 1.29 \\
\hline Minnesota & 4.59 & 1.28 & 1.12 & 1.18 \\
\hline Mississippi & 0.85 & 1.13 & 0.76 & 1.14 \\
\hline Missouri & 2.48 & 0.84 & 1.52 & 2.08 \\
\hline Montana & 0.46 & 0.67 & 0.92 & 1.07 \\
\hline Nebraska & 2.07 & 1.29 & 1.16 & 1.00 \\
\hline Nevada & 0.78 & 0.66 & 0.95 & 0.87 \\
\hline New Hampshire & 2.15 & 0.94 & 0.95 & 0.93 \\
\hline New Jersey & 2.05 & 1.56 & 1.25 & 1.30 \\
\hline New Mexico & 1.03 & 1.90 & 0.81 & 1.73 \\
\hline New York & 2.41 & 0.95 & 1.54 & 1.08 \\
\hline North Carolina & 1.06 & 1.23 & 0.93 & 1.19 \\
\hline North Dakota & 0.03 & 0.85 & 0.94 & 1.16 \\
\hline Ohio & 2.20 & 1.71 & 1.48 & 1.68 \\
\hline Oklahoma & 1.81 & 1.73 & 0.58 & 1.33 \\
\hline Oregon & 1.61 & 0.94 & 0.72 & 0.81 \\
\hline Pennsylvania & 0.98 & 1.32 & 0.91 & 1.55 \\
\hline Rhode Island & 0.97 & 0.94 & 1.06 & 0.97 \\
\hline
\end{tabular}




$\begin{array}{lllll}\text { South Carolina } & 1.03 & 0.95 & 0.78 & 0.74 \\ \text { South Dakota } & 0.23 & 0.99 & 0.43 & 1.18 \\ \text { Tennessee } & 2.56 & 1.53 & 1.17 & 1.26 \\ \text { Texas } & 1.19 & 1.76 & 0.82 & 1.24 \\ \text { Utah } & 1.42 & 1.28 & 0.73 & 1.25 \\ \text { Vermont } & 1.14 & 1.00 & 1.00 & 1.50 \\ \text { Virginia } & 1.11 & 0.68 & 3.17 & 3.06 \\ \text { Washington } & 1.15 & 0.78 & 1.00 & 1.27 \\ \text { West Virginia } & 0.80 & 1.32 & 0.74 & 0.96 \\ \text { Wisconsin } & 4.79 & 1.97 & 1.55 & 1.51 \\ \text { Wyoming } & 2.09 & 1.75 & 3.59 & 1.75 \\ \text { National } & \mathbf{1 . 4 6} & \mathbf{1 . 4 1} & \mathbf{1 . 1 1} & \mathbf{1 . 3 3}\end{array}$

